logos_i_ethos_2018_2_(48), s. 81-98

DOI: http://dx.doi.org/10.15633/lie.2786

Robert Grzywacz SJ

https://orcid.org/0000-0001-8353-6238

Akademia Ignatianum w Krakowie

\title{
Krucha podmiotowość, czyli o sporze na gruncie Lévinasowskiej i Ricœurowskiej filozofii człowieka oraz niektórych jego implikacjach dla rozumienia zdrowia psychicznego
}

Poniższe studium stawia sobie jako zadanie skonfrontowanie dwóch koncepcji kruchej podmiotowości: jednej autorstwa Emmanuela Lévinasa i drugiej, wypracowanej przez Paula Ricœura. Zestawienie to nie jest wszelako celem samym w sobie. Owszem, chodzi w nim najpierw o wskazanie zbieżności i rozbieżności istniejących pomiędzy obydwoma ujęciami otwartego i labilnego w swej tożsamości ludzkiego podmiotu. Krok ów służy dalej uwydatnieniu punktów dyskusyjnych, które wskutek napięcia generowanego przez niezgodności pobudzają do myślenia i poszukiwania mediacji. W celu zilustrowania płodności tej kon-
Robert Grzywacz SJ - doktor filozofii, adiunkt w Instytucie Filozofii Akademii Ignatianum w Krakowie. Współredaktor i autor trzech monografii naukowych: Michel Henry - fenomenolog życia (z A. Gielarowskim, Kraków 2010), Między przedmiotowością a podmiotowością: intencjonalność $w$ fenomenologii francuskiej/ Entre lobjectivité et la subjectivité: lintentionnalité dans la phénoménologie française (z A. Gielarowskim, Kraków 2011), W trosce o człowieka. Paradygmaty stare i nowe (z M. Szymczyk, Kraków 2016), autor wprowadzenia i przekładu zbioru artykułów P. Ricœura: Nazwać Boga. Teksty Paula Ricœura (Kraków 2011) oraz kilku artykułów naukowych nt. filozofii P. Ricœura, M. Henry’ego i M. Foucaulta. Zainteresowania badawcze: filozofia współczesna, hermeneutyka filozoficzna, fenomenologia (filozofia P. Ricœura, M. Henry’ego, M. Foucaulta, J. Habermasa): antropologia filozoficzna, tożsamość podmiotu, narracyjne koncepcje tożsamości i ich zastosowania, zagadnienie podmiotu i dyskursu przekonań.

trowersji zostaje ona przeniesiona na obszar filozofii psychiatrii, gdzie podejmuje się próbę zastosowania obydwu antropologicznych stanowisk 
w filozoficznej interpretacji istoty fenomenu schizofrenii. Zarysowana w ten sposób wykładnia patogenezy wybranego zjawiska pozwala z kolei na sformułowanie ostrożnych wniosków odnośnie do samego sporu Lévinasa i Ricœura w kwestii podmiotowości etycznej.

\section{Dwa ujęcia kruchej podmiotowości}

Obydwaj myśliciele, których poglądy stanowią przedmiot poniższych rozważań, traktowani są tutaj jako przedstawiciele filozofii człowieka ${ }^{1}$. Ich zestawienie można w znacznej mierze uzasadnić rzeczywistym dialogiem między nimi, prowadzonym w duchu głębokiego wzajemnego szacunku, a jednocześnie niepozbawionym polemiki ${ }^{2}$. Obydwaj wypracowali w swoich dziełach koncepcje podmiotowości naznaczonej egzystencjalną kruchością. W przypadku Lévinasa najzwięźlej należałoby ją określić jako podmiotowość odseparowanej gościnności i substytucji za drugiego. W stosunku do Ricœura wolno by mówić o podmiotowości niedomkniętej dialektyki ${ }^{3}$.

Lévinasowski podmiot, z perspektywy dwóch głównych dzieł filozofa $^{4}$, charakteryzuje dynamika postępującej radykalizacji, jeśli chodzi o swoiste „wywłaszczenie”, które dotyka konstytutywnego dla subiektywności momentu bycia-u-siebie, swojskości. O ile bowiem takie pojęcia, jak separacja, wewnętrzność, psychika, rozkoszowanie się czy ekonomia wskazują jeszcze na oswajanie i przyswajanie inności przez Toż-Samego, na monadyczność „z zatrzaśniętymi oknami”5 (Tischner), o tyle pragnienie sygnalizuje już gościnność wobec Transcendencji, a nawet odpowiedzialność poprzedzającą i usprawiedliwiającą wolność podmiotu.

1 Por. D. Rogóż, Anty-Odyseja. Antropologia Emmanuela Lévinasa, Kraków 2012, s. 18, 24-31; P. Ricœur, Żyć aż do śmierci oraz fragmenty, tłum. A. Turczyn, Kraków 2008, s. 109-110.

2 Por. F. Dosse, Paul Ricœur. Les sens d’une vie (1913-2005), Paris 2008, s. 637-641.

3 Por. M. Kowalska, Wstęp. Dialektyka bycia soba, w: P. Ricœur, O sobie samym jako innym, tłum. B. Chełstowski, Warszawa 2018, s. XXXVII; A. Warmbier, Tożsamość, narracja i hermeneutyka siebie. Paula Ricœura filozofia człowieka, Kraków 2018, s. 36-52, 65-67.

4 E. Lévinas, Całość i nieskończoność. Esej o zewnętrzności, tłum. M. Kowalska, Warszawa 1998; E. Lévinas, Inaczej niż być lub ponad istotą, tłum. P. Mrówczyński, Warszawa 2000.

5 J. Tischner, Spór o istnienie człowieka, Kraków 2011, s. 282-284. 
Jak powiada Lévinas: „Z rozmówcą nie jestem na «ty», lecz na "pan». Objawia się on w swoim panowaniu. Zewnętrzność jest więc tym samym, co funkcja nauczycielska. Moją wolność podważa Mistrz, który może dać mi do niej prawo"6. A równocześnie nie ma tu mowy o całkowitym wywłaszczeniu, wręcz odwrotnie - gościnność zakłada separację w ,jej absolutnej prawdzie i radykalności”: „transcendencja twarzy nie wydarza się poza światem, jakby ekonomia separacji dokonywała się na niższym poziomie niż szczęśliwa kontemplacja Innego. [...] skupienie się w domu otwartym dla Innego - gościnność - stanowi konkretny i źródłowy fakt ludzkiego skupienia i separacji, pokrywający się z pragnieniem absolutnej transcendencji Innego"7. Dopiero w Inaczej niż być lub ponad istotą opis znacząco się zmienia wraz z takimi określeniami, jak wrażliwość i bliskość, podatność na zranienie i substytucja: „Podmiotowość jako inny w to ż-s amym - jako natchnienie - jest kwestionowaniem wszelkiej afirmacji «dla siebie», wszelkiego egoizmu [...] jest odpowiedzialnością lub byciem-zakwestionowanym jako całkowite odsłonięcie się na zniewagę policzka nadstawionego w stronę tego, który uderza"8. A nieco dalej Lévinas wyraża się jeszcze dosadniej: „Ipseitas, w swojej biernej, pozbawionej arche tożsamości, jest zakładnikiem. [...] Cofanie się do siebie staje się tożsamością, przerywając granice tożsamości, rozsadzając zasadę bycia we mnie, niedopuszczalny spoczynek w sobie charakteryzujący definicję. Sobość pozbawiona spoczynku: niemożliwość odwrócenia się od wszystkiego, by «troszczyć się tylko o siebie», ale docieranie do siebie przez udrękę. [...] Inny w Toż-samym oznacza moją substytucję innego zgodnie z odpowiedzialnością, do której zostałem wyznaczony jako ktoś niezastępowalny"9. W tak oto szkicowo zrekonstruowanym ruchu - od separacji, poprzez gościnność, aż do substytucji za innych - dokonuje się radykalne „wywłaszczenie”, wyobcowanie podmiotowości $\mathrm{w}$ traumatyzującym doświadczeniu

6 E. Lévinas, Całość i nieskończoność, dz. cyt., s. 110.

7 E. Lévinas, Całość i nieskończoność, dz. cyt., s. 201.

8 E. Lévinas, Inaczej niż być..., dz. cyt., s. 187.

9 E. Lévinas, Inaczej niż być..., dz. cyt., s. 192. 
odpowiedzialności za drugiego ${ }^{10}$. Monada „z zatrzaśniętymi oknami” przeradza się w "monadę, która cała jest otwarciem «dla innego»" ${ }^{11}$, jest "tylko jednym wielkim otwartym oknem" ${ }^{12}$.

Z kolei u Ricœura ludzka podmiotowość uzyskuje swoje rozmaite determinacje nade wszystko $\mathrm{w}$ dynamice wielowymiarowej dialektyki, niezwieńczonej na poziomie egzystencjalnym żadną ostateczną syntezą. Dialektyka ta w sferze wolitywnej obejmuje interakcje czynników zależnych od woli (decydowanie, działanie wraz z wprawianiem ciała w ruch, przyzwolenie na przeżywaną konieczność w postaci charakteru, tego, co nieświadome, oraz życia jako niepodzielnej jednostki organizacji i wzrostu, rozciągniętej czasowo od narodzin do śmierci) oraz czynników mimowolnych (cielesność oraz dopiero co wymienione wyrazy podmiotowo przeżywanej konieczności ${ }^{13}$ ). Ta opisana w badaniu istotowym dialektyka dobrowolności i mimowolności na płaszczyźnie empirycznej wpisuje się w inną relację dialektyczną, obecną w każdym z trzech wymiarów człowieczej skończoności i nieskończoności egzystencjalnej: teoretycznym, praktycznym i uczuciowym. Na polu teoretycznym zawężenie perspektywy poznawczej przekraczane jest dzięki mowie i znaczeniu, w obszarze praktycznym jednostkowość charakteru, czyli ograniczone praktyczne i motywacyjne otwarcie podmiotu na świat ulega nieskończonemu poszerzeniu wraz z dążeniem do szczęścia, natomiast w dziedzinie afektywności izolowane uczucia witalne otwierają się na całościowy, szczęściorodny horyzont uczuć duchowych. Ta egzystencjalna dialektyka tworzy zręby tzw. ontologii dysproporcji, która streszcza się w danej przeżyciowo inherentnej niewspółmierności człowieka, czyniącej zeń istotę kruchą uczuciowo, a w konsekwencji omylną, ułomną ${ }^{14}$. Rzeczona

10 Por. D. Rogóż, Anty-Odyseja, dz. cyt., s. 36-46.

11 J. Tischner, Spór o istnienie człowieka, dz. cyt., s. 285.

12 J. Tischner, Spór o istnienie człowieka, dz. cyt., s. 303.

13 Zob. P. Ricœur, Philosophie de la volonté, t. 1: Le volontaire et l'involontaire, Paris 2009, passim; A. Warmbier, Tożsamość, narracja i hermeneutyka siebie, dz. cyt., s. 95-118; R. Grzywacz, Wybrane aspekty rozumienia natury ludzkiej w ujęciu Paula Ricœura, w: Oblicza natury ludzkiej. Studia i rozprawy, red. P. Duchliński, G. Hołub, Kraków 2010, s. 201-208.

14 Zob. P. Ricœur, Philosophie de la volonté, t. 2: Finitude et culpabilité, livre 1: L'Homme faillible, Paris 2009, s. 35-193; J. Jakubowski, Skończoność egzystencjalna. Studium nad filozofią Paula 
kruchość przekłada się na niestabilny charakter ludzkiej tożsamości - tożsamości typu narracyjnego, łączącej w sobie elementy bardziej kronikarskie z tymi silnie interpretacyjnymi, twórczymi ${ }^{15}$. Ale równocześnie na tę dialektyczną chwiejność czy oscylację narracyjnej tożsamości wpływa samo jej ukonstytuowanie jako ogniwa pośredniczącego między spolaryzowanymi składowymi: tą bardziej przedmiotową (charakter jako całokształt względnie trwałych dyspozycji, nabytych utożsamień znamionujących daną osobę) i tą bardziej podmiotową (zachowanie siebie $\mathrm{w}$ dotrzymanym słowie, w wierności) ${ }^{16}$. Co więcej, kruchość ludzkiej podmiotowości wzmaga jej nieodłączny - i znów dialektyczny - związek z innością: własnego ciała, relacyjnego otwarcia na drugiego człowieka, a także sumienia ${ }^{17}$. Związek ów uruchamia tym samym dialektykę na kolejnych poziomach: podtrzymywania siebie i oderwania się od siebie, pamięci i zapomnienia, działania i doznawania, zdolności i niezdolności, autonomii oraz podatności na zranienie ${ }^{18}$. To właśnie nieusuwalny charakter owych stosunków dialektycznych sprawia, że Ricœurowska podmiotowość jest stale otwarta i znajduje się w stanie „chwiejnej równowagi"19.

Ricœura, Bydgoszcz 2017, s. 260-326; E. A. Mukoid, Filozofia zła: Nabert, Marcel, Ricœur, Kraków 1993, s. 53-54; R. Grzywacz, Wybrane aspekty rozumienia natury ludzkiej..., dz. cyt., s. 208-215; R. Grzywacz, Afektywność i język. Tożsamość człowieka $w$ fenomenologii życia M. Henry oraz $w$ fenomenologii hermeneutycznej P. Ricœura, w: W trosce o człowieka. Paradygmaty stare i nowe, red. M. Szymczyk, R. Grzywacz, Kraków 2016, s. 186-188.

15 Zob. P. Ricœur, Czas i opowieść, t. 3: Czas opowiadany, tłum. U. Zbrzeźniak, Kraków 2008, s. 356 .

16 Zob. P. Ricœur, O sobie samym jako innym, dz. cyt., s. 200-207.

17 Zob. P. Ricœur, O sobie samym jako innym, dz. cyt., s. 529-591.

18 Zob. P. Ricœur, O sobie samym jako innym, dz. cyt., s. 278-279; P. Ricœur, Pamięć, historia, zapomnienie, tłum. J. Margański, Kraków 2007, s. 554-585, 663-667; P. Ricœur, Cierpienie nie jest bólem, w: P. Ricœur, Filozofia osoby, tłum. M. Frankiewicz, Kraków 1992, s. 55-61; P. Ricœur, Le Juste, t. 2, Paris 2001, s. 85-105.

19 Por. A. Wierciński, Celebrating the Confusion of Voices and the Fusion of Hermeneutic Horizons, w: Between Suspicion and Sympathy. Paul Ricour's Unstable Equilibrium, ed. A. Wierciński, Toronto 2003, s. XI. 


\section{Zbieżności i rozbieżności między porównywanymi koncepcjami podmiotowości}

Zarówno Lévinas, jak i Ricœur tworzą filozofię antysystemową i zgadzają się co do „ludzkiej unikalności zaimka ja, nieredukowalnego do scalenia, do ogólności jakiegoś jednego rodzaju"20. Obydwaj uznają podmiotowość za otwartą, gościnną, niechybnie konfrontującą się $\mathrm{z}$ innością, i to innością rozumianą tyleż jako radykalnie zewnętrzną, co uwewnętrznioną, aż po rozbijanie samej struktury podmiotowości do tego stopnia gościnnej. Tym samym obydwaj myśliciele stają się protagonistami „kruchej” podmiotowości, uwzględniając i doceniając w niej wymiar bierności, jakkolwiek odmiennie przez każdego z nich pojmowany i akcentowany.

Zdaniem Lévinasa kruchość polega na rodzącej etyczny opór nagości twarzy Drugiego, innego człowieka ${ }^{21}$, a po stronie Toż-Samego, który wchodzi w relację z absolutną Zewnętrznością, Transcendencją - na ambiwalencji separacji i ekonomii wewnętrzności ${ }^{22}$, na wrażliwości, źródłowej bierności, podatności na zranienie, krótko mówiąc: na skrajnej ekspozycji - na nawiedzenie, opętanie, prześladowanie, traumę, status zakładnika ${ }^{23} \mathrm{z}$ racji odpowiedzialności za Innego - i na dynamice niedającego się zaspokoić pragnienia, nawet jeśli w płodzeniu spełnia się ono poniekąd, nie niknąc całkowicie ${ }^{24}$.

Według Ricœura kruchość tkwi w niedającym się ukoić „sercu” człowieka, niezdolnym do urzeczywistnienia jakiejś ostatecznej syntezy uczuciowej. Człowiek bowiem musi stale pośredniczyć pomiędzy potencjalnie nieograniczonym uczestnictwem w rozumności a ograniczoną perspektywą dostępu do jej zasobów; pomiędzy nieograniczonym pragnieniem szczęścia i pełni a ograniczonością własnego charakteru,

20 E. Lévinas, P. Ricœur, L’unicité humaine du pronom Je, w: Éthique et responsabilité. Paul Ricœur, ed. J.-Ch. Aeschlimann, Boudry-Neuchâtel 1994, s. 37 (tłum. R. G.).

21 Zob. E. Lévinas, Całość i nieskończoność, dz. cyt., s. 74-75, 234.

22 Zob. E. Lévinas, Całość i nieskończoność, dz. cyt., s. 128-130, 302, 360-362.

23 Zob. E. Lévinas, Inaczej niż być..., dz. cyt., s. 30-32, 85-88, 108-147, 208-210, 216-217.

24 Zob. E. Lévinas, Całość i nieskończoność, dz. cyt., s. 326, 367. 
motywacyjnej orientacji; a wreszcie pomiędzy witalnymi uczuciami, skoncentrowanymi na doraźnej przyjemności, a bardziej intelektualnym i całościowym pragnieniem szczęścia ${ }^{25}$. Kruchość polega również na nieusuwalnej chwiejności ludzkiej tożsamości narracyjnej, rozpostartej między względnie trwałym biegunem charakterologicznych dyspozycji a nieustannym podtrzymywaniem siebie w wierności danemu słowu, złożonym obietnicom ${ }^{26}$. Jednakże jej niestabilność nie tylko tkwi w jej dialektycznej pozycji, lecz wiąże się także z aspektem jednostkowej wyjątkowości, niezastępowanej perspektywy indywidualnej, dotyczącej np. źródłowej nieprzekazywalności wspomnień ${ }^{27}$. Bardziej ogólnie rzecz ujmując, człowiecza kruchość ma swe źródło w braku trwałego epistemologicznego i ontologicznego fundamentu, który byłby oparciem dla ciągle podejrzanych i podatnych na krytykę przekonań podmiotu, a także gwarantem przekraczalności ograniczeń, które blokują tkwiące w nim możliwości ${ }^{28}$. Rozważana niestabilność wynika więc również z rozmaitych niezdolności, stanowiących przeciwwagę dla ludzkich zdolności, przez które definiuje się podmiotowość (samoidentyfikacji, mówienia, działania, opowiadania/o sobie, pamiętania, obiecywania, poczytalności i odpowiedzialności), a w rezultacie sens autonomii ulega znaczącej transformacji, uwzględniając wyraźniej wymiar cierpienia i patologii ${ }^{29}$.

Obok pewnych zbieżności, zasygnalizowanych jedynie w bardzo ogólnych zarysach, między omawianymi myślicielami istnieją wszelako istotne kontrasty. W pierwszej kolejności, ważna różnica zachodzi już na poziomie wewnętrznej dynamiki rozwoju samej myśli omawianych autorów. W projekcie Lévinasa motywem wiodącym staje się zwłaszcza postępujące wyobcowanie Toż-Samego w Innym, aż po nawiedzenie, prześladowanie, opętanie Toż-Samego przez Innego, bycie jego

25 Zob. P. Ricœur, Philosophie de la volonté, t. 2, dz. cyt., s. 175-183.

26 Zob. P. Ricœur, O sobie samym jako innym, dz. cyt., s. 207.

27 Zob. P. Ricœur, Le Juste, t. 2, dz. cyt., s. 94-95.

28 Por. C. Sautereau, Subjectivité et vulnérabilité chez Ricœur et Lévinas, „Études Ricœuriennes/ Ricœur Studies" 4 (2013) no 2, s. 9-15.

29 Zob. P. Ricœur, Le Juste, t. 2, dz. cyt., s. 85-105, 215-226. 
zakładnikiem, zastąpienie go ${ }^{30}$. Radykalizm tego wyobcowania sięga tak daleko, że podmiotowość nie jest już w stanie powrócić do egoistycznego bycia-u-siebie, do beztroskiej ekonomii własnej wewnętrzności. Myśl Ricœura rozwija się dialektycznie, konsekwentnie unikając ostatecznych syntez $^{31}$. Zgodnie ze spuścizną filozofii refleksji porusza się po „okrężnej drodze”, od niekrytycznego rozumienia, poprzez metodyczne wyjaśnianie, po rozumienie krytyczne. Tym samym ten-który-jest-sobą wyobcowuje się w starciu z innością (głównie z obiektywizacjami kultury, rozmaitymi konfiguracjami tekstowych światów), ulega wywłaszczeniu, dezorientacji, które wszakże prowadzi go koniec końców do momentu przyswojenia, nowej orientacji we własnym świecie, przeobrażonym przez to spotkanie. Powraca zatem do siebie, choć znajduje siebie już innego od samego siebie sprzed okrężnego ruchu samorozumienia, i w tym sensie nie niweczy przez absorpcję napotykanej inności w obrębie swojej tożsamości ${ }^{32}$.

Zarysowana odmienność dynamiki rozwoju samej myśli u obydwu autorów wydaje się w dalszej kolejności rzutować, przynajmniej częściowo, na inne znaczące punkty rozejścia się ich koncepcji podmiotu. Wspomnijmy kilka $z$ nich. Lévinas uważa, że zasadniczo różni go od Ricœura skupienie się na relacjach pozbawionych wzajemności, zawsze asymetrycznych, całkowicie dobrowolnych i bezinteresownych, nawet za cenę niesprawiedliwości wobec siebie, akceptacji kondycji zakładnika, słowem: koncentracja na relacjach miłości czy świętości ${ }^{33}$. Ricœur natomiast dostrzega u Lévinasa systematyczne stosowanie przesadni argumentacyjnej: najpierw w określeniu Toż-Samego przez separację, a następnie - i konsekwentnie - w uznaniu Innego za absolutną Zewnętrzność, Transcendencję, Wysokość uwalniającą się z relacji i zjawiającą się

30 Zob. E. Lévinas, Inaczej niż być..., dz. cyt., s. 192.

31 Zob. P. Ricœur, Podług nadziei. Odczyty, szkice, studia, tłum. S. Cichowicz, M. Łukasiewicz i in., Warszawa 1991, s. 55-56, 83-85.

32 Zob. P. Ricœur, Czas i opowieść, t. 3, dz. cyt., s. 354; P. Ricœur, O sobie samym jako innym, dz. cyt., s. 33-34, 592.

33 Por. M. de Saint-Cheron, Rozmowy z Emmanuelem Lévinasem, tłum. K. Kot, Warszawa 2008, s. 29-31; E. Lévinas, P. Ricœur, L'unicité humaine du pronom Je, dz. cyt., s. 36. 
w epifanii Twarzy, która w istocie jest głosem. Końcowym akordem tej hiperboli jest podmiotowość zastępująca krzywdziciela w akcie ekspiacji ${ }^{34}$. Przesadna separacja wewnętrzności pociąga za sobą, zdaniem Ricœura, nadmierną eksterioryzację Transcendencji. A wówczas rodzi się pytanie, czy gdyby „wewnętrzność określała się tylko przez samą wolę wycofania się i zamykania w sobie, jak kiedykolwiek usłyszałaby słowo, które byłoby dla niej jako dla wyspiarskiej egzystencji tak obce, że byłoby jakby niczym?"35. Wynika stąd nieodzowność przyznania podmiotowości refleksyjnej zdolności przyjmowania, a dalej także rozróżniania i rozpoznawania (uznawania), by potrafiła np. odróżnić Innego jako mistrza czy nauczyciela od krzywdziciela i oprawcy, a także przyjąć nakaz jako swoje własne przekonanie ${ }^{36}$. Owa zdolność uznawania wezwania czy też nakazu płynącego ze strony Innego wiąże się w szczególny sposób, według Ricœura, z budzeniem przezeń poważania siebie w przyjmującym to wezwanie lub nakaz, a więc z pozytywnym poruszeniem w sferze afektywności i z możliwością przedłużania wymiany dawania i otrzymywania ${ }^{37}$. Można by uzupełnić te uwagi o jeszcze jedno pytanie: czy bezinteresowność poświęcenia siebie w substytucji nie jest de facto u Lévinasa innym imieniem wolności ${ }^{38}$ Wydaje się zatem, że o ile autor Całości i nieskończoności trafnie sytuuje punkt poróżnienia z Ricœurem w obecności bądź braku wzajemności w opisywanym przezeń stosunku do drugiego człowieka, o tyle pozostaje w mocy pytanie zadane przez francuskiego hermeneutę, czy czysta bezinteresowność nie zakłada jednak takiego pobudzenia podmiotowości do odpowiedzialności, które

34 Zob. P. Ricœur, O sobie samym jako innym, dz. cyt., s. 558-566.

35 P. Ricœur, O sobie samym jako innym, dz. cyt., s. 564.

36 Ten oto punkt przesądza u Ricœura o swoistości sumienia jako figury inności różnej od inności drugiego człowieka: bycie-pod-wpływem-nakazu jako struktura bycia sobą. Zob. P. Ricœur, O sobie samym jako innym, dz. cyt., s. 590. Choć w indywidualnej praktyce staje się ona u niego wysoce problematyczna. Por. M. I. Wallace, The Irony of Selfhood in Paul Ricour's Hermeneutic Philosophy, w: Between Suspicion and Sympathy..., dz. cyt., s. 168-170.

37 Zob. E. Lévinas, P. Ricœur, L’unicité humaine du pronom Je, dz. cyt., s. 37; P. Ricœur, O sobie samym jako innym, dz. cyt., s. 314.

38 Rzecz jasna, wolności potwierdzanej w czynach chwalebnych, heroicznych, w wymiarze supererogacji. 
to pobudzenie miałoby coś wspólnego z perspektywą poważania siebie. Lévinas zaś najwyższą godność dostrzega dokładnie w akceptacji kondycji zakładnika ${ }^{39}$. Osobną i niebagatelną rolę w omawianej kontrowersji odgrywa pozycja trzeciego, która zdaniem Ricœura nie ustępuje pod względem pierwszeństwa poważaniu siebie ani relacji z Drugim, a którą utożsamia on z pozycją samego mówiącego w swoim dziele Lévinasa ${ }^{40}$. $\mathrm{Na}$ cały ten spór można zresztą spojrzeć jak na polemikę w sprawie fundacyjnego pierwszeństwa miłości (agape) bądź sprawiedliwości oraz miejsca wzajemności ${ }^{41}$, z uwzględnieniem wszelako „dystansu wpisanego w bliskość" ${ }^{42}$.

\section{Podmiotowość zdrowa, czyli jaka? \\ Zastosowanie Lévinasowskiej i Ricœurowskiej filozofii człowieka do metaklinicznych rozważań w psychiatrii}

W kontekście obydwu rozważanych koncepcji „kruchej” podmiotowości postawienie kwestii zdrowia psychicznego wydaje się zasadne. Lévinas sam podpowiada taki kierunek refleksji, kiedy pisze: „Psychika jest formą zdumiewającego rozszczepienia - rozluźnienia lub rozprężenia - tożsamości: jest toż-samym nie mogącym zejść się z samym sobą, toż-samym rozdartym i wyrwanym $z$ odpoczynku, między snem a bezsennością, utratą tchu, dreszczem. Nie znaczy to, że Toż-samy, wyobcowany i zniewolony przez innego, abdykuje, ale że zapomina o sobie w odpowiedzialności za innego. Jego tożsamość zostaje jednocześnie potwierdzona i zakwestionowana przez odpowiedzialność i służbę dla

39 Por. M. de Saint-Cheron, Rozmowy z Emmanuelem Lévinasem, dz. cyt., s. 31-32.

40 Zob. P. Ricœur, Autrement. Lecture d'Autrement quêtre ou au-delà de l'essence d'Emmanuel Lévinas, Paris 1997, s. 32, 35-37; E. Lévinas, Inaczej niż być..., dz. cyt., s. 260, 262; E. Lévinas, P. Ricœur, L'unicité humaine du pronom Je, dz. cyt., s. 37.

${ }^{41}$ Zob. P. Ricœur, Drogi rozpoznania. Wykłady Instytutu Nauk o Człowieku w Wiedniu, tłum. J. Margański, Kraków 2004, s. 154-157, 266-268. Więcej nt. sporu Lévinas - Ricœur zob. m.in. w: J. Tischner, Spór o istnienie człowieka, dz. cyt., s. 300-306; M. Drwięga, Człowiek między dobrem a złem. Studia z etyki wspótczesnej, Kraków 2012, s. 61-70; J. Jakubowski, Skończoność egzystencjalna, dz. cyt., s. 188-192; A. Warmbier, Tożsamość, narracja i hermeneutyka siebie, dz. cyt., s. 319-333.

42 P. Ricœur, Drogi rozpoznania, dz. cyt., s. 267. 
innego. Za sprawą odpowiedzialności psychiczność duszy staje się innym we mnie; chorobą tożsamości, która jest zarazem zakwestionowana, oskarżona i pozostaje s ob ą, stając się tożsamością za innego, tożsamością przez innego. [I dalej w przypisie:] Dusza jest innym we mnie. Psychika, jeden-za-drugiego, może być opętaniem i psychozą; dusza jest już zalążkiem szaleństwa"43. Zagadnienie zdrowia psychicznego można więc powiązać w tym ujęciu z „sobością pozbawioną spoczynku”, o której Lévinas powiada, iż znamionuje ją „niemożliwość odwrócenia się od wszystkiego, by «troszczyć się tylko o siebie», ale docieranie do siebie przez udrękę" Interesująca nas problematyka zbliża się wówczas do propozycji sformułowanej niegdyś przez Kazimierza Dąbrowskiego, który definiuje zdrowie psychiczne jako „zdolność do rozwoju w kierunku wszechstronnego rozumienia, przeżywania, odkrywania i tworzenia coraz wyższej hierarchii rzeczywistości i wartości, aż do konkretnego ideału indywidualnego i społecznego"45, gdzie niepoślednią rolę odgrywają procesy tzw. „dezintegracji pozytywnej”. Odwołanie to pozwala na uwydatnienie ambiwalencji otwartej struktury podmiotowości w kontekście jej dobrostanu.

Przyjrzyjmy się na koniec możliwym aplikacjom rozpatrywanych koncepcji. Szczególnie odpowiednie dla tego celu pole badań wydaje się stanowić fenomen schizofrenii, na temat którego powstała już pokaźna literatura z zakresu filozofii psychiatrii. Bywa on określany jako uszczerbek zdroworozsądkowych kompetencji praktycznych, odejście od naturalnego nastawienia wobec świata, skrajny czy graniczny przypadek ludzkiej kondycji, alienacja z przejawami anomalii socjalizacyjnych, lub też porażka człowieczego świata ${ }^{46}$. Poniżej zostaną naszkicowane zaledwie dwa przykładowe ujęcia zaburzeń dobrostanu ludzkiej podmiotowości w schizofrenii: jedno ucieka się do pomocy Lévinasowskiej filozofii człowieka, a drugie korzysta z antropologii Ricœurowskiej.

43 E. Lévinas, Inaczej niż być..., dz. cyt., s. 116-117.

44 E. Lévinas, Inaczej niż być..., dz. cyt., s. 192.

45 K. Dąbrowski, Co to jest zdrowie psychiczne?, w: Zdrowie psychiczne, red. K. Dąbrowski, Warszawa 1985, s. 29.

46 Por. A. Kapusta, Szaleństwo i metoda. Granice rozumienia w filozofii i psychiatrii, Lublin 2010, s. 118-119, 145-146, 151-154, 286-303. 
Antoni Jarnuszkiewicz ${ }^{47}$ za Antonim Kępińskim ${ }^{48}$ odnotowuje, że w interesującym nas przypadku szczególną doniosłość posiada problem tożsamości Ja, a dokładnie granicy własnej tożsamości i kryzysu jej identyfikacji w odniesieniu do demarkacji między wewnętrznością a otoczeniem (jej „pęknięcie” albo „puchnięcie”). Przywoływany autor odróżnia Ja-metafizyczne, czyli elementarną nieintencjonalną przytomność siebie i Drugiego, od Ja-psychicznego, czyli świadomości intencjonalnej, stanowiącej sposób przeżywania Ja-metafizycznego (gdy jest on nieadekwatny, mamy do czynienia z Ja-psychologicznym). Co więcej, Ja-metafizyczne może się znajdować w pozycji etycznej, a więc być pojęte jako separacja $\mathrm{w}$ sensie Lévinasowskim, bądź też w pozycji agatologicznej, w której odpowiada gościnności, bliskości z Innym. Schizofrenia będzie $\mathrm{w}$ tym podejściu polegać na rozwarstwieniu Ja-psychologicznego (a więc Ja-psychicznego nieadekwatnego względem metafizycznego) od Ja-metafizycznego. Antropologia Lévinasowska służy tu zatem do opisu trzech podstawowych momentów źródłowego doświadczenia metafizycznego: 1) separacji Ja i absolutnej transcendencji Drugiego, 2) gościnności Ja umożliwiającej bliskość płynącą z wybrania przez Dobroć ${ }^{49}$, oraz 3) mediacyjnej obecności Trzeciego, który, jak powiada Jarnuszkiewicz ,wyzwala z dialogu, i to wyzwolenie przez trialog jest jakby przejawem [...] wyzwolenia z symbiotycznych relacji, które miałyby być podpórkami istnienia substancjalnego" ${ }^{50}$. Sytuacje schizofrenogenne naruszają właśnie na poziomie Ja-psychologicznego te momenty doświadczenia metafizycznego, np. wskutek „naduwikłania", obciążenia nadmierną odpowiedzialnością, w efekcie czego dziecko „zmuszane jest przemocą do zatracania przytomności swojej jednostkowej, etycznej tożsamości, przez mieszanie aprobaty osobowej (koalicji etycznej, niezwiązanej z rolami w rodzinie) z dyspozycyjnością

\footnotetext{
47 A. Jarnuszkiewicz SJ, Od systemu do etyki. Krytyka rozumu dialogicznego, Kraków 2012, s. 105-125.

48 A. Kępiński, Schizofrenia, Warszawa 1981, s. 191-218; por. J. Tischner, Myślenie według wartości, Kraków 1982, s. 404-412.

49 Por. E. Lévinas, Inaczej niż być..., dz. cyt., s. 208.

50 A. Jarnuszkiewicz SJ, Od systemu do etyki, dz. cyt., s. 116.
} 
funkcjonalną (instrumentalnością bycia w roli)" ${ }^{\text {51 }}$. Dopiero Trzeci i stąd jego terapeutyczna funkcja - jest w stanie rozbić symbiotyczną diadę relacyjną, w którą uwikłane jest Ja, pomagając mu odkryć niezależność jego odseparowanej substancjalności (metafizycznego Ja-agatologicznego) od ty z relacji uwikłania (uwalniając od psychologicznego Ja-aksjologicznego ${ }^{52}$. Przejdźmy do drugiej z rozpatrywanych interpretacji fenomenu schizofrenii.

Giovanni Stanghellini i René Rosfort ${ }^{53}$ prezentują bardzo interesujące zastosowanie antropologii Ricœurowskiej w obszarze filozoficznej refleksji nad problemami psychiatrii ${ }^{54}$. Dostrzegają w niej bowiem szczególnie cenne ujęcie intencjonalno-uwewnętrzniającej funkcji uczuć (jako przeciwieństwa dynamizmu obiektywizacji), które $\mathrm{z}$ tej funkcjonalnej racji sytuują się na styku transcendencji i immanencji. Ów przysługujący im status wynika $\mathrm{z}$ ich odniesienia do przedpredykatywnego, przedrefleksyjnego stosunku człowieka do świata, a więc ich umiejscowienia u podstaw ludzkiej przynależności do świata, wyrażającej się w zachowaniu (np. w skłonnościach) i w samej „kruchej” sferze uczuciowości. Istotna okazuje się także ich ścisła korelacja z poznaniem, tak iż można mówić u człowieka o racjonalności emocjonalnej. W tym kontekście cytowani autorzy utrzymują, że u osób ze schizofrenią nie mamy do czynienia z jakimś szczególnym rodzajem złego nastroju, jak smutek czy złość, ale raczej z głęboką zmianą samej możliwości doznawania. Interpretują oni schizofrenię jako zaburzenie nastroju (w sensie odczuć egzystencjalnych ${ }^{55}$ ), polegające nade wszystko na osłabieniu poczucia przynależności do świata i udziału $\mathrm{w}$ wysiłku istnienia. Tymczasem to źródłowe odczucie pełni fundacyjną rolę w konstytucji swojego bycia sobą i w relacji wcielonej podmiotowości do świata. Dostarcza bowiem ukrytej świadomości własnej wewnętrznej integracji oraz rzeczywistości,

51 A. Jarnuszkiewicz SJ, Od systemu do etyki, dz. cyt., s. 117.

52 Por. A. Jarnuszkiewicz SJ, Od systemu do etyki, dz. cyt., s. 124.

53 G. Stanghellini, R. Rosfort, Emotions and Personhood. Exploring Fragility - Making Sense of Vulnerability, Oxford 2013.

54 Por. A. Kapusta, Szaleństwo i metoda, dz. cyt., s. 236-240.

55 Por. A. Kapusta, Szaleństwo i metoda, dz. cyt., s. 276-282. 
pozwalając na swoiste zestrojenie z zewnętrznym światem w sposób, który okazuje się kontekstowo trafny, bez zniekształcania czy wypaczania osobistych celów, wartości czy tożsamości. Właśnie to źródłowe poczucie jest zagrożone u osób ze schizofrenią. W rezultacie wyłania się nadmiernie racjonalna forma egzystowania, w której nie dostrzega się w innych żywych podmiotów, lecz zobiektywizowane, anonimowe mechanizmy, zewnętrzne wobec własnego ciała i samego siebie ${ }^{56}$. Kluczowe dla dobrostanu bądź jego braku okazuje się zatem odczuwanie własnego Ja, zdolność lub, przeciwnie, trudności z uchwyceniem własnej jedności i integralności. Ucieleśnienie i zaangażowanie w świat znajdują bowiem swoje uczuciowe i emocjonalne przejawy. Toteż Ricœurowska hermeneutyczna antropologia okazuje się w tym miejscu wielce pomocna, podkreślając ontologiczną dysproporcję nieodłączną od bycia sobą, przedrefleksyjną niestabilność i konfliktowość, które to bycie stanowią. Uwydatnia ona kruche napięcie, na stałe wpisane w ludzką tożsamość zarówno w wymiarze biologicznym, jak i osobowym. Na tej idei konfliktowej integracji wewnętrznej, która odnosi się tyleż do osób zdrowych, co zaburzonych, zasadza się przywołany pokrótce dialektyczny model patologii psychicznej.

\section{Wnioski}

Przeprowadzone dociekania pozwalają docenić diagnostyczną wartość wybranych poglądów antropologicznych dla metaklinicznej refleksji w psychiatrii. Ponadto wskazują one pośrednio na wzajemne korygowanie się obydwu podejść w filozofii człowieka. Antropologia Lévinasowska okazuje się celna nie tylko w swoim ruchu radykalizacji w pojmowaniu odpowiedzialności, kosztem wyobcowania podmiotowości, ale i w koncepcji separacji tej ostatniej ${ }^{57}$. Tymczasem Ricœurowskie stanowisko antropologiczne zyskuje na podkreśleniu roli wymiarów egzystencjalnej przynależności i uczuciowości w ludzkim byciu-w-świecie. Aspekty

56 Por. G. Stanghellini, R. Rosfort, Emotions and Personhood, dz. cyt., s. 11, 221-260.

57 Por. J. Tischner, Spór o istnienie człowieka, dz. cyt., s. 303-304. 
te wprawdzie znalazły w nim swoje miejsce już we wczesnej fazie jego rozwoju $^{58}$, lecz były coraz mniej eksplorowane na „okrężnej drodze” przemierzanej przez „późnego” Ricœura. Wolno zatem skonkludować, że obydwie rozpatrywane propozycje filozoficzne ujawniają swój diagnostyczny potencjał odczytywane nie tylko zgodnie z inherentnym dla każdej z nich porządkiem chronologicznym, ale i regresywnie. Być może obie dyskutowane filozofie człowieka mają również dla siebie nawzajem wartość instruktywną w stosunku do samego punktu ich poróżnienia, a mianowicie korekcyjnej roli miłości (u Ricœura ${ }^{59}$ ) i sprawiedliwości (u Lévinasa ${ }^{60}$ ).

\section{Bibliografia}

Dąbrowski K., Co to jest zdrowie psychiczne?, w: Zdrowie psychiczne, red. K. Dąbrowski, Warszawa 1985, s. 7-35.

Dosse F., Paul Ricour. Les sens d'une vie (1913-2005), Paris 2008.

Drwięga M., Człowiek między dobrem a złem. Studia z etyki wspótczesnej, Kraków 2012. Grzywacz R., Afektywność i język. Tożsamość człowieka w fenomenologii zycia M. Henry oraz $w$ fenomenologii hermeneutycznej P. Riccura, w: W trosce o człowieka. Paradygmaty stare i nowe, red. M. Szymczyk, R. Grzywacz, Kraków 2016, s. 179-194. Grzywacz R., Wybrane aspekty rozumienia natury ludzkiej w ujęciu Paula Ricœura, w: Oblicza natury ludzkiej. Studia i rozprawy, red. P. Duchliński, G. Hołub, Kraków 2010, s. 195-224.

Jakubowski J., Skończoność egzystencjalna. Studium nad filozofia Paula Ricœura, Bydgoszcz 2017.

Jarnuszkiewicz A. SJ, Od systemu do etyki. Krytyka rozumu dialogicznego, Kraków 2012. Kapusta A., Szaleństwo i metoda. Granice rozumienia w filozofii i psychiatrii, Lublin 2010. Kępiński A., Schizofrenia, Warszawa 1981.

Kowalska M., Wstęp. Dialektyka bycia soba, w: P. Ricœur, O sobie samym jako innym, tłum. B. Chełstowski, Warszawa 2018, s. VII-XXXVII.

58 Zob. P. Ricœur, A l'école de la phénoménologie, Paris 2004, s. 315-331.

59 P. Ricœur, Miłość i sprawiedliwość, tłum. M. Drwięga, Kraków 2010, s. 46-51.

60 E. Lévinas, Całość i nieskończoność, dz. cyt., s. 252-254, 361. 
Lévinas E., Ricœur P., L’unicité humaine du pronom Je, w: Éthique et responsabilité. Paul Ricœur, ed. J.-Ch. Aeschlimann, Boudry-Neuchâtel 1994, s. 35-37.

Lévinas E., Całość i nieskończoność. Esej o zewnętrzności, tłum. M. Kowalska, Warszawa 1998. Lévinas E., Inaczej niż być lub ponad istotą, tłum. P. Mrówczyński, Warszawa 2000.

Mukoid E. A., Filozofia zła: Nabert, Marcel, Ricœur, Kraków 1993.

Ricœur P., A l'école de la phénoménologie, Paris 2004.

Ricœur P., Autrement. Lecture d'Autrement qu'être ou au-delà de l'essence d'Emmanuel Lévinas, Paris 1997.

Ricœur P., Cierpienie nie jest bólem, w: P. Ricœur, Filozofia osoby, tłum. M. Frankiewicz, Kraków 1992, s. 55-63.

Ricœur P., Czas i opowieść, t. 3: Czas opowiadany, tłum. U. Zbrzeźniak, Kraków 2008.

Ricœur P., Drogi rozpoznania. Wykłady Instytutu Nauk o Człowieku w Wiedniu, tłum. J. Margański, Kraków 2004.

Ricœur P., Le Juste, t. 2, Paris 2001.

Ricœur P., Miłość i sprawiedliwość, tłum. M. Drwięga, Kraków 2010.

Ricœur P., O sobie samym jako innym, tłum. B. Chełstowski, Warszawa 2018.

Ricœur P., Pamięć, historia, zapomnienie, tłum. J. Margański, Kraków 2007.

Ricœur P., Philosophie de la volonté, t. 1: Le volontaire et l'involontaire, Paris 2009.

Ricœur P., Philosophie de la volonté, t. 2: Finitude et culpabilité, livre 1: L’Homme faillible, Paris 2009, s. 35-199.

Ricœur P., Podług nadziei. Odczyty, szkice, studia, tłum. S. Cichowicz, M. Łukasiewicz i in., Warszawa 1991.

Ricœur P., Żyć aż do śmierci oraz fragmenty, tłum. A. Turczyn, Kraków 2008.

Rogóż D., Anty-Odyseja. Antropologia Emmanuela Lévinasa, Kraków 2012.

Saint-Cheron M. de, Rozmowy z Emmanuelem Lévinasem, tłum. K. Kot, Warszawa 2008.

Sautereau C., Subjectivité et vulnérabilité chez Ricœur et Lévinas, „Études Ricœuriennes/ Ricour Studies" 4 (2013) no. 2, s. 8-24.

Stanghellini G., Rosfort R., Emotions and Personhood. Exploring Fragility - Making Sense of Vulnerability, Oxford 2013.

Tischner J., Myślenie według wartości, Kraków 1982.

Tischner J., Spór o istnienie człowieka, Kraków 2011.

Wallace M. I., The Irony of Selfhood in Paul Ricour's Hermeneutic Philosophy, w: Between Suspicion and Sympathy. Paul Ricour's Unstable Equilibrium, ed. A. Wierciński, Toronto 2003, s. 161-171. 
Warmbier A., Tożsamość, narracja i hermeneutyka siebie. Paula Ricœura filozofia człowieka, Kraków 2018.

Wierciński A., Celebrating the Confusion of Voices and the Fusion of Hermeneutic Horizons, w: Between Suspicion and Sympathy. Paul Ricour's Unstable Equilibrium, ed. A. Wierciński, Toronto 2003, s. IX-XIV.

\section{Abstrakt}

\section{Krucha podmiotowość, czyli o sporze na gruncie Lévinasowskiej i Ricœurowskiej filozofii człowieka oraz niektórych jego implikacjach dla rozumienia zdrowia psychicznego}

Poniższe studium stawia sobie jako zadanie skonfrontowanie dwóch koncepcji kruchej podmiotowości: jednej autorstwa Emmanuela Lévinasa i drugiej, wypracowanej przez Paula Ricœura. Zestawienie to nie jest wszelako celem samym w sobie. Owszem, chodzi w nim najpierw o wskazanie zbieżności i rozbieżności istniejących pomiędzy obydwoma ujęciami otwartego i labilnego w swej tożsamości ludzkiego podmiotu. Krok ów służy dalej uwydatnieniu punktów dyskusyjnych, które wskutek napięcia generowanego przez niezgodności pobudzają do myślenia i poszukiwania mediacji. W celu zilustrowania płodności tej kontrowersji zostaje ona przeniesiona na obszar filozofii psychiatrii, gdzie podejmuje się próbę zastosowania obydwu antropologicznych stanowisk w filozoficznej interpretacji istoty fenomenu schizofrenii. Zarysowana w ten sposób wykładnia patogenezy wybranego zjawiska pozwala z kolei na sformułowanie ostrożnych wniosków odnośnie do samego sporu Lévinasa i Ricœura w kwestii podmiotowości etycznej, a zwłaszcza co do odczytania ewolucji ich własnych koncepcji.

\section{Słowa kluczowe}

krucha podmiotowość, Lévinas, Ricœur, zdrowie psychiczne, schizofrenia 


\section{Abstract \\ Fragile Subjectivity: About a Controversy on the Ground of Lévinas' and Ricœur's Philosophical Anthropology and Some of its Implications for the Understanding of Mental Health}

The study aims to confront two concepts of fragile subjectivity: one by Emmanuel Lévinas and the other by Paul Ricœur. However, this is not the purpose in itself. Actually, the first step consists on the pointing out the similarities and divergences that exist between both approaches in dealing with the open and labile trait of human identity. This step further serves to highlight the discussion points which, due to the tension generated by the underlined incompatibilities, stimulate thinking and the search for mediation. To illustrate the fertility of this controversy, it is transferred to the area of philosophy of psychiatry, where an attempt is made to apply both anthropological positions to a philosophical interpretation of the essence of the phenomenon of schizophrenia. This interpretation of the pathogenesis of the chosen phenomenon allows, in turn, for a cautious conclusion to be drawn as to the described controversy between Lévinas and Ricœur.

\section{Keywords}

fragile subjectivity, Lévinas, Ricœur, mental health, schizophrenia 